\title{
Emirati and Saudi Students' Writing Challenges at U.S. Universities
}

\author{
Ghadah Al Murshidi ${ }^{1}$ \\ ${ }^{1}$ College of Education, UAE University, UAE \\ Correspondence: Ghadah Al Murshidi, College of Education, UAE University, UAE. Tel: 97-137-136-462. \\ E-mail: g_almurshidi@uaeu.ac.ae
}

Received: February 19, $2014 \quad$ Accepted: April 2, $2014 \quad$ Online Published: May 14, 2014
$\begin{aligned} & \text { doi:10.5539/elt.v7n6p87 } \quad \text { URL: http://dx.doi.org/10.5539/elt.v7n6p87 }\end{aligned}$

\begin{abstract}
The study examines writing challenges Emirati and Saudi students face at U.S. universities. Based on a sample of 219, a mixed methods approach was used to analyze responses from the participants. The results of the questionnaire reveal that Less than 31\% Emirati and Saudi students feel "comfortable" in completing written assignments. The interviews results indicate that Emirati and Saudi students have different opinions regarding writing difficulties. An Emirati student, stated: "I am worried a lot because writing is not easy. Writing is very difficult for us." However, a Saudi student expressed the easiness of her writing assignments. Emirati students stated that grammar, word choice and sentence construction are "somewhat easy"; however, Saudi students indicated that grammar, word choice and sentence construction are "Somewhat difficult." An Emirati student, stated: "Most Arabs students are told that we do not have vocabulary or grammar. For me, grammar is okay but my difficulty is how to choose the appropriate word for a sentence. A female Emirati student expressed her worry for grammatical mistakes, which she tries to correct: "When I write my reports, I have to reread my report again because I am sure I will have some grammatical mistakes because English is not my first language. The study implies that the students need more coursework in academic writing to prepare them for their academic writing in their disciplines. U.S. universities need to increase the visiting hours of writing centers and design more workshops that teach the students about writing in various genres.
\end{abstract}

Keywords: second language socialization, academic literacy socialization, writing challenges

\section{Introduction}

This study analyzes my story and the stories of Emirati and Saudi students' writing challenges in the United States Universities. The following sections in this study tell this story and analyze what the findings mean for future studies in higher education in the Gulf countries and the USA. A scan of the literature reveals little or no significant studies have been done to the population of students who are from the United Arab Emirates or Saudi Arabia and I believe research on this their writing challenges will be important to educators and policymakers.

In recent informal conversations with Emirati and Saudi students at U.S. Universities, I learned that they experience challenges and struggles in their first year compared to the succeeding years of study as they may lack certain linguistic capital that is necessary to successfully function in their disciplines, particularly at the doctoral level. Some of these students got shocked and lost when they did not get support in their academic work from their classmates, instructors or friends. As a result of their linguistic barriers, they kept silent during discussions in class. As some studies have indicated, some international students view themselves as less competent and linguistically less experienced.

The highly interactive and collaborative nature of post-secondary education in the US (i.e., writing papers, working on group projects, making presentations inside and outside the classroom, engaging in academic conversations and discussions), collectively demand Western academic literacy practices and require individuals to construct pieces of writing on the way to becoming scholars in their chosen disciplinary realms. Stories of these challenges, which are still happening repeatedly on a daily basis for many international students, need to be told, documented, and analyzed. Clearly, these are only some of the motivating factors that persuade me to look further into this phenomenon.

This study's value accrues to sponsors of international students, particularly for its potential to expose fault lines in higher education and study-abroad preparatory programs that are inattentive to the needs of first-time international students attending American Universities. A scan of available literature reveals few or no recent, 
noteworthy studies involving Gulf-region scholastic endeavors. This study becomes extremely important for retention programs and for educators and policymakers in the Gulf-region and elsewhere.

\section{Literature Review}

\subsection{Second Language Socialization}

Some second language socialization studies conducted to investigate elementary, secondary and post-secondary students' socialization process in different contexts such as Canada. Other studies focused on immigrants' interactive challenges in elementary, secondary, and post-secondary classrooms in the U.S and Canada (Duff, 2002; Harklau, 2003; Kobayashi, 2003; Norton, 1995, 1997, 2000; Norton \& Toohey, 2001; Morita, 2000, 2004; Toohey, 1998). These studies showed the significance of second language speaking and writing strategies, and scaffolding and peer feedback in new academic communities.

Notably therefore, dampening of students' academic socializations and linguistic and conceptual repertoires has occurred, since international graduate students' typical training concentrates on English-as-a-second-language for cognitive or academic functions within formal contexts only. They may lack informal, culturally appropriate, social use of the language in within the context of American college culture. As noted in this review, language difficulties cause problems to cascade. For instance, informal, casually made remarks, the use of slang and euphemisms, and a lack of English proficiency reduce socio-academic acclimatization, and international students often miss vital information.

\subsection{Academic Literacy Socialization}

Literacy socialization and language socialization complement each other. This section discusses situated and multiple academic literacy (Cope \& Kalantzis, 2000; Barton et al., 2000; Hull \& Schultz, 2000; Street, 1984; Lea \& Street, 1999). This theoretical consideration applies to the academic literacy socialization process of Emirati and Saudi students. A study of literacy socialization concerns students' learning the norms of their academic communities, the students' academic socialization and learning processes of second language academic literacy, and the process of acquiring legitimacy in their academic communities.

Several studies attempted to investigate the academic and social processes internationalstudents' undergo to succeed in their academic disciplines. In the study of academic literacy socialization, scholars examined the rhetorical and linguistic continuum in acquisition of academic Englishwriting skills (e.g., Brett, 1994; Swales, 1990), academic voices and identities (e.g., Hirvela \& Belcher, 2001; Ivanic \& Camps, 2001), relationships between students' vernacular communities and their academic communities (e.g., Belcher, 1999; Canagarajah, 2002), and students' academic discourse socialization processes and experiences, with emphasis on writing (e.g., Belcher, 1995; Casanave, 1995, 2002; Prior, 1995; Spack, 1997; Zamel, 1998, 2000).

Based on the language socialization framework, some researchers examined literacy socialization in different situations. For example, Heath (1987), for some children, investigated the use of language and writing in the home and school, merged language and literacy socialization theories, and demonstrated the effect of children's written interaction and cultural practices at home and school with writing proficiency. Other researchers, such as Barton (1994) and Barton and Hamilton (1998) studied the development of the social view of literacy. Barton's (1994) view of literate practices emphasized the connection between individuals and their social environments.

Literate practices focus on "(A)n ecological approach is...one which examines the social and mental embeddedness of human activities in a way which allows change (Barton, 1994, p. 32). Grounded in the Street and Heath social views of literacy, Barton and Hamilton (2000) identified literate practices as "the link between the activities of reading and writing and the social structures in which they are embedded and which they help shape" (Barton \& Hamilton, 2000, p. 7), and literacy events as "activities where literacy has a role" (p. 8). The perception of literacy's situation is one of daily social processes (Barton et al., 2000), "positioned in relation to the social institutions and power relations which sustain them" (Barton et al., 2000, p. 1).

Other researchers use the concept of literacy in its plural form to refer to a variety of knowledge and competencies (e.g., computer literacy, visual literacy, political literacy, culturalliteracy and academic literacy). The social view of literacy also refers to being "competent and knowledgeable in specialized areas" (Barton, 1994, p. 19). Viewing the plural form of literacy broadens the conceptualization of an individual's connections with literacy. The first and second language research and theories of literacy turn scholars' attention to the ideological view of literacy. Some researchers conducted ethnographic studies to understand the learners who have diverse linguistic and cultural backgrounds that emphasize the social, cultural and political processes of their conflicting literacy experiences in U.S. and non-U.S. contexts.

Grounded in the L1 literacy field, Street $(1984,1993)$ defined two literacy models, which are the "autonomous 
and the "ideological." First, the autonomous model of literacy reflects literacy as isolated skills, independent of social context (product oriented). Second, theideological model of literacy refers to literacy as culturally and politically involved practices (process oriented). Literacy, viewed in the ideological model, is "inextricably linked to cultural and power structures in society" and recognizes "the variety of cultural practices associated with reading and writing in different contexts" (Street, 1993, p. 7). Street (1984, p. 12) conducted ethnographic studies and analyzed different literacy practices such as a study of Iranian villagers' reading and writing practices, which employed the ideological perspective of literacy practices. Street believed that literacy practices include individual's knowledge of reading and writing and "behavior and conceptualizations related to the use of reading and writing". Street conducted many studies in different places throughout the world showing the disconnection between the pedagogies teachers use in literacy practices and local people's ways of performing these literacy practices.

Lea and Street (2000) identified three models according to three contexts of literacy socialization in higher education research: study skills, academic socialization, and academic literacy. The study skills model represents the autonomous literacy perspective that emphasizes writing skills and knowledge isolated from any particular context. The academic socialization and academic literacy models are embedded in institutional contexts. The study skills view focuses on the mechanical characteristics of language (e.g., grammar and spelling) and the significance of teaching these skills outside any specific context. Based on the model of these skills, teachers' instruction encourages students to focus on the technical aspects of writing. This model accrued criticism from its lack of addressing the needs and expectations of students who have different linguistic and cultural backgrounds, and the contexts brought to learning the reading and writing skills. This criticism led some scholars to investigate the perspective that learning academic writing is a process of academic socialization that includes more than justlearning the technical aspects of writing. Negotiation of meaning and students' enculturation into new discourses and discourse practices is the focus of the academic socialization model; therefore, the context is significant for acquiring the literacy.

Overall, these studies indicate that international students face many challenges to accommodate the different discourses needed to succeed (Lea \& Street, 2000). Students face challenges in their studies when beginning to acquire new sets of literacy practices. Therefore, the academic literacy model, as Street (2005) contended, "targets the institutions themselves and the professional development of tutors as well as the students 'needs' for academic support, and it stresses the need for unpacking and making explicit what is taken for granted in terms of literacy requirements" (p. 6).

\subsection{The Gulf Region Students' Linguistics Challenges}

The Gulf region countries encompass the states of Bahrain, the United Arab Emirates, Saudi Arabia, Qatar, Kuwait, Oman, Iraq, and Islamic Republic of Iran. Emirati and Saudi students are considered Gulf region students as well because they are from the Gulf region countries. The rapid development has had influence on the strategic planning of the English language preparation programs. The Gulf region countries are multicultural and multilingual countries which their populations speak Arabic, Urdu/Hindi, Malayalam, and especially English. Policy makers in these countries encouraged learning English to keep up with the modernization, which is a significant subject to teach in their curriculum at all educational levels. However, Gulf region students see no significance in communicating in English in their native countries where the surroundings are mostly communicating in the native language, Arabic. English might not be used beyond their classroom (Syed, 2003).

Emirati and Saudi students are considered Arabs. They face similar challenges as Arab learners because they share common language and culture. For instance, Arab learners of English face difficulties in speaking and writing (Haq, 1982; Harrison, Prator, \& Tucker, 1975; Abbad, 1988; Wahab, 1998). For instance, Jordanian students learn English in their native countries which the official language is Arabic as the Gulf region countries. The opportunities of learning and practicing English naturally are very limited to communicating with tourists.

The most obvious problems that hinder the progress of Arab students at University level may be attributed to the "inadequate mastery of the four language skills; namely listening, speaking, reading and writing" (Sulieman, 1983, p. 129). The Arabs students face difficulty in communicating in the target language at the university level (Sulieman, 1983) The native language, Arabic, interference is not the only factor of the Arab students" challenges, but the teaching and language process also contribute to their challenges in English (Rababah, 2002) .

\section{Research Design and Method}

The focus of this research is a comparative study of Saudi and Emirati students who transition into U.S. universities. To attain the main purpose of this study requires responding, the constituents of this inquiry are: 
What writing challenges do Emirati and Saudi students face at U.S. universities? What are the Emirati and Saudi students' coping strategies to face their challenges? The study is a mixed-method approach that integrates quantitative and qualitative strategies involving surveying 219 students followed by interviews. Research criterion-based purpose sampling (Patton, 2002) frame of this study was used that includes selection of students from different US universities who are Gulf-region natives. For the quantitative data, the researcher created a database to store the results from the Quartlics website. The Statistical Package for Social Sciences (SPSS) 16.0 was utilized to conduct statistical analyses. The researcher calculated and identified the mean, range, and standard deviation scores for all these categories using SPSS software. Moreover, inferential statistical tests included $t$-test was used. The qualitative strategy provided an opportunity for the voices of Emirati and Saudi students to emerge. It gave a descriptive analysis of six Emirati and Saudi students' experiences. The interviews were coded to themes for analysis (thematic analysis). Content analysis was utilized to interpret the data. Member checks of the survey questions and interview is employed (Merriam, 2002) in this study assures validity. This study is part of a larger study that examines linguistics challenges of Emirati and Saudi students in the U.S. Universities.

\section{Results}

This section presents some of the findings of the questionnaire and the interviews.

\subsection{Survey Results}

The main results that the questionnaire indicates are as followed based on two research questions:

Questionnaire results related to research question 1: what writingchallenges do Emirati and Saudi students face at U.S. universities?

Regarding the comfort level of doing written assignments, $27.8 \%$ of Emirati students indicated feeling "comfortable" completing written assignments. Similarly, 30.5\% of Saudi students stated being "comfortable" completing written assignments.

\subsubsection{Challenges Encountered by Emirati and Saudi Students in Writing Papers}

Seven items measured challenges students encountered for completing writing assignments (grammar, word choice, sentence construction, organization, concept, and theory). Table 3 summarizes the results. Differences between Saudi and Emirati students were significant for two of those challenges. First, Saudi students reported grammar was not easy $(\mathrm{M}=4.08, \mathrm{SD}=1.75)$, as did Emirati students $(\mathrm{M}=4.61, \mathrm{SD}=1.63)$. This difference was significant $(\mathrm{p}=0.03)$ and represents a small effect difference $($ Cohen $d=0.31)$. Emirati students $(27.1 \%)$ indicated that grammar was "somewhat difficult." In comparison, $22.5 \%$ of Saudi students indicated that grammar is "easy." Second, Saudi students reported word-choice (diction) was not as easy ( $\mathrm{M}=3.72, \mathrm{SD}=1.46$ ) as did Emirati students $(\mathrm{M}=4.46, \mathrm{SD}=1.48)$. This difference is significant $(\mathrm{p}=<0.01)$ and represents a medium effect difference (Cohen $d=0.50)$. Emirati students $(29.4 \%)$ reported word-choice to be "somewhat difficult" in writing. On the other hand, $26.7 \%$ of Saudi students mentioned concepts to be "somewhat easy" (See Tables 4- and 5). No significant differences are apparent in means between Saudi students and Emirati students for the other five challenges.

When deciding to remove a natural option from analysis, three considerations are necessary: First, when removing a neutral option, the number of people in the analysis decreases by about $20-25 \%$. Second, the important examination is the degree of change means. Examining the means in the two tables, very little change in values is apparent. This represents be evidence that leaving the neutral option in the analysis is appropriate. Third, the size of the standard deviations increases slightly from removing the neutral option; fewer participants explain the expected phenomenon. Since removing the neutral options causes little change in mean values, the neutral option could remain in the analysis (See Tables 5, 6 (a) and 6 (b).

Questionnaire results related to research question 2: how do Emirati and Saudi students cope with these writing challenges to succeed in the U.S. universities?

\subsubsection{Improving Writing}

When Emirati and Saudi students indicated the use of their native "Arabic" for writing ideas and then translating to English, the highest number of Emirati students (44.1\%) and Saudi students (41.8\%) professed to use English when initiating writing activities. The difference between Saudi and Emirati students was insignificant; Emirati students reported that they avoided beginning to write in Arabic and then translating to English $(\mathrm{M}=1.76$; $\mathrm{SD}$ $=.85)$ as did Saudi students $(\mathrm{M}=1.91 \mathrm{SD}=.99)($ See Tables 7, 8, and Figure 1). 
When asking Emirati and Saudi students to identify the areas for emphasis in writing, $17.7 \%$ of Emirati students and $20.5 \%$ of Saudi students indicated writing style, and $31.6 \%$ of Emirati students and $23.9 \%$ of Saudi students indicated an emphasis on content. Both style and content were areas of emphases for $47.9 \%$ of Emirati students and $62.0 \%$ of Saudi students (See Table 9).

\subsection{Interview Results}

This section presents some of the interview analysis to its themes, and organized based on the first and second research questions.

4.2.1 Research Question 1: What Writingchallenges Do Emirati and Saudi Students Face at U.S. Universities?

Theme 1: Linguistics Challenges (Writing, Vocabulary, and Grammar)

Emirati and Saudi students identified linguistic challenges in their writing that influence the language socialization process in classrooms. English vocabulary and grammar are linguistics aspects which Emirati and Saudi students emphasized as creating difficulties. Emirati student "Zayed" expressed his difficulty in understanding American accents, and some Saudi students' claimed linguistic difficulties prevent them from participating in class.

Hassan commented:

My language when I came here was very poor. I have the basics only. This is an important problem which Saudi students face. $90 \%$ of Saudi students are not proficient in English.

Khalifah commented:

At the beginning, I was silent in the classroom in the language preparation program. I was afraid to talk. My linguistics ability was zero. I was shy, afraid to talk and make mistakes because others may laugh.

Writing Challenges

Some comments identify writing difficulty; Khaled commented:

I am worried a lot because writing is not easy. Writing is very difficult for us.

Khaled emphasized that writing is always a challenge for himself and his Emirati peers:

This semester I worked with two American students and one of my Emirati friends. I and my friend are not good at writing because writing is always a challenge for us

In working with a group of Emirati students and two American students, Khaled expressed his upset from a low grade because of his writing weakness. His response to the low grade is:

If my student partnere were American, it would be better a little bit because he will know how to write. He will be proficient in English. The American students did not care about our work. I and my Emirati friend were writing to reach 300 words. We write and sit to think deeply. We give the ideas to the American students and he reaches 500 words. We have ideas but we do not know how to express our ideas and write them fluently.

Khalifah commented:

When I was in the language preparation program, I was writing around 250 words for preparation for IELTS. When I started my first class in college, the teacher told us to write around 1000 words. I was shocked and thinking how I will write that. I was thinking why I came to this university?

Sheikha commented:

Today, I had submitted a report for my class. It was easy. It had two tables and was reporting results of our project. I enjoy doing reports more than just essays".

Vocabulary and Grammar Challenges

Emirati students indicated vocabulary and grammar difficulties.

Zayed commented:

Most Arabs students told that not having vocabulary or grammar is difficult. For me, grammar is okay but my difficulty is how to choose the appropriate word for a sentence.

Hoor commented:

When I write my reports, I have reread my report again because I am sure I will have some grammatical mistakes because English is not my first language. I used to write immediately without revision. At the end, I try to edit the paper which takes double the time of writing the report itself because while I am editing I feel that 
some new ideas come up so I want to add them but I do not know how to add them. This process takes time.

4.2.2 Research Question 2: How Do Emirati and Saudi Students Cope with these Writing Challenges to Succeed in the U.S. Universities?

Theme 2: Improving Writing Skills

Emirati and Saudi students indicated that academic writing is a difficulty they face. Their past schooling experiences did not prepare them to write academically especially in English. Their assignments were writing simple paragraphs which they memorize most of the time. They are aware of their writing difficulty; therefore, most of them attempt to improve by attending more writing courses, visiting writing centers, and using dictionaries:

\section{Writing Courses}

Some of the participants commented on their experiences in their writing courses and the benefits received.

Khaled commented:

I wrote a paper about fire safety in $202 \mathrm{C}$ writing class. The paper was about 15 pages with pictures. This paper was individual. Also, I learned how to cite, write and modify our writing only from English 15. I use Word Document and a website called Easy Citation. I enter the book name, the date of publication, and then I choose MLA, or APA, or Chicago. MLA is free but for other types of citations, I have to have register. The name of the website is easyBib. It means easy bibliography. There are many websites like that. Also, at the end of English 15, the teachers told us to go to a website about the citation after we learned how to do that. Honestly, it was good that they did that because I learned how to do it manually.

Hassan commented:

If anyone wants to write a paragraph or essay, he has to have the basics. What we have learned here is we have to write introduction, body and conclusion because these are basics to write a paragraph. Of course, writing a body in an essay is different from one teacher to another. Every person has his/her own style. Then, I will provide more details and examples.

Hoor commented:

I took ESL 15 and other writing courses in the language preparation program, which prepare me to write biology lab reports and other research papers. I learned how to write reports, paraphrase and cite correctly.

\section{Writing Center}

Some Emirati and Saudi students visited the writing center for help editing their papers. However, their expectations might not be met, as Khalifah commented:

I go to the writing center to edit my papers. However, the writing center helps me $10 \%$. They ignore some of the mistakes. I have to get an appointment. I have to wait days to get that appointment and get my chance. When I have the appointment, I read the paper loudly. The editor will highlight some mistakes. The editor does not tell us how to correct the mistakes. I did not like the editor's way of helping me in my writing because I was my first year in college. It was my first time to write a paper. I did not write more than 300 words. I think if the editor in the writing center explains to me my mistakes, these rules will stick in my mind."

Hoor expressed her preference to have a native speaker of English edit her papers:

I revise my papers in the writing center which I prefer because the editors are native English speakers"

Sheikha's worrier for her grades encourages her to visit the writing center:

I go to the writing Centre especially when a paper weight a high grade. In ESL 15 course, I was writing a paper when I was on Facebook and I got A. Now, I got A- for my papers. I have to focus on my writing to get A in this course which is demanding.

Using dictionaries

Emirati and Saudi students use dictionaries for translating the unfamiliar vocabulary. Hassan described his use of the dictionary:

The dictionary is necessity for me and I think other students as well. For instance, if a word is in Arabic and I want to know it in English, I will translate it.

Khalifah commented:

Oxford Dictionary was my close friend when I am writing to use it for translation from English to Arabic. 


\section{Theme 3: Improving Vocabulary}

Emirati and Saudi students recognize the importance of vocabulary which is critical to writing success because comprehension improves when the students know what the words mean. When the students improve their vocabularies, their academic and social confidences and competencies improve.

Vocabulary use and comprehension

Students expend great effort to learn vocabulary However; they still face difficulties expressing ideas succinctly. The students use different strategies for learning vocabulary and its use though writing. Regarding vocabulary use, Zayed commented:

In writing, I usually use many words just to explain a meaning of a specific word which I do not know.

Unique way of learning vocabulary

Hassan described his unique way of improving his vocabulary:

I am trying to improve my vocabulary. I am using a way to learn vocabulary for a month now approximately. I am trying to write paragraphs which are already written. I use the TOEFL book. I rewrite the paragraphs to learn English. If I did not understand vocabulary in a paragraph, I translate it because I am sure it will come again in the essay. When I read it once and twice, I will memorize it. This is a way I am using for a month now.

\section{Discussion and Conclusions}

The major findings of this study allow discussion of writing challenges.

Socialization occurs when bilingual or multilingual students learn the language of academia through their interaction with students more proficient in the language and who have more cultural knowledge of the target academic communities' capabilities for mentoring or learning appropriate uses of language, ideologies, values, and identities of community members (Duff, in press). Current study shows that the majority of Emirati and Saudi students prefer to work with English native speakers for class presentations or writing projects. Zayed, an Emirati student, did his work with American students who are proficient in English, so the writing part was their responsibility. He stated: "During this summer, we have American classmates in our group. They wrote the report. We did the presentation. We brought the needed materials."

The literature suggested some dimensions and variables that influence international students' adjustment problems. Notably, perhaps, of the most important are language difficulties (Klineberg \& Hull, 1979). The current study shows that some Emirati and Saudi interviewees expressed their linguistic challenges in their writing affect their language socialization process in their classrooms. English vocabulary and grammar are linguistics aspects which Emirati and Saudi students emphasized as creating difficulties.

Emirati and Saudi students indicate that they are "less comfortable" in doing writing assignments and presentations. Emirati students are "less comfortable" with reading assignments than Saudi students. Emirati and Saudi students have different opinions regarding writing difficulties. Khaled, an Emirati student, stated: "I am worried a lot because writing is not easy. Writing is very difficult for us." However, Sheikha, a Saudi student, expressed the easiness of her writing assignments; "Today, I had submitted a report for my class. It was easy. It had two tables and was reporting results of our project. I enjoy doing reports more than just essays." These different opinions of writing difficulties result from students' different linguistic proficiencies and language preparation programs. Sheikha, had agood preparation program at ARAMCO and her parents' Englishpreparation in herearly years prepared her for academic writing. However, Khaled's public schools did not prepare him for sophisticated academic writing in English.

Several studies attempted to investigate the academic and social processes international students' undergo to succeed in their academic disciplines. In the study of academic literacy socialization, scholars examined the rhetorical and linguistic continuum in acquisition of academic English writing skills (e.g. Brett, 1994; Swales, 1990). Hoor, an Emirati student, expressed her experience of learning to write biology lab reports that are required in her academic community: "I took ESL 15 and other writing courses in the language preparation program which prepared me to write biology lab reports and other research papers. I learned how to write reports, paraphrase, and cite correctly." Hoor, an Emirati student, also learned specific skills to use particular databases for writing research papers: "My major is biology. I used some databases for writing my research. Our teachers teach us how to use these databases and guide us on the process of using the databases. Before using any program, teachers teach us how to use them. Also, if we find difficulties in using these programs and databases, teaching assistants help us as well. We have to go to the teaching assistants early before the class starts."

Lea and Street (2000) identified three models according to three contexts of literacy socialization in higher 
education research: study skills, academic socialization, and academic literacy. The study skills model represents the autonomous literacy perspective that emphasizes writing skills and knowledge isolated from any particular context. The study skills' view focuses on the mechanical characteristics of language (e.g., grammar and spelling) and the significance of teaching these skills outside any specific context. Based on the model of these skills, teachers' instruction encourages students to focus on the technical aspects of writing, which Emirati and Saudi students used to focus on for their English learning. Regarding challenges encountered by Emirati and Saudi Students in writing papers, the current study shows that Emirati students stated that grammar, word choice and sentence construction are "somewhat easy"; however, Saudi students indicated that grammar, word choice and sentence construction are "Somewhat difficult." Emirati and Saudi students still face difficulties using appropriate grammar or word, as Zayed, an Emirati student, stated: "Most Arabs students are told that we do not have vocabulary or grammar. For me, grammar is okay but my difficulty is how to choose the appropriate word for asentence." Moreover, Hoor, a female Emirati student, expressed her worry for grammatical mistakes, which she tries to correct: "When I write my reports, I have to reread my report again because I am sure I will have some grammatical mistakes because English is not my first language. I used to write immediately without revision. At the end, I try to edit the paper, which takes double the time of writing the report itself because while I am editing I feel that some new ideas come up so I want to add them but I do not know how to add them. This process takes time from me." This model accrued criticism from its lack of addressing the needs and expectations of students who have different linguistic and cultural backgrounds, and the contexts brought to learning reading and writing skills. This criticism led some scholars to investigate the perspective that learning academic writing is a process of academic socialization that includes more than just learning the technical aspects of writing. Negotiation of meaning and students' enculturation into new discourses and discourse practices is the focus of the academic socialization model; therefore, the context is significant for acquiring literacy. Zayed, an Emirati student, emphasized the significance of the context to comprehend vocabulary: "While I am reading, I do not use dictionary. Since I was child, I used to understand the meaning of the new vocabulary from the context." Zayed identified movies, with particular contexts, for learning vocabulary: "Watching a movie is easier because we can understand the meaning of some new vocabulary from the body movement." Zayed added: "I watch movies and I learn the vocabularies while I am watching. I read the subtitles." Also, Hassan, a Saudi student, uses movies' contexts to learn English vocabulary: "I watch movies. Every night, I have to watch at least one movie to learn more words."

Study findings have several implications specifically for Emirati and Saudi students, their sponsors, U.S. universities and their language preparation programs. First, Emirati and Saudi students need more coursework in academic writing to prepare them for their academic writingin their disciplines. Additionally, U.S. universities need to increase the visiting hours of writing centers and design more workshops that teach the students about writing in various genres.

\section{References}

Barton, D. (1994). Literacy: An introduction to the ecology of written language. Oxford, UK: Blackwell.

Barton, D., \& Hamilton, M. (1998). Local literacies: Reading and writing in one community. London: Routledge.

Barton, D., Hamilton, M., \& Ivanic, R. (Eds.). (2000). Situated literacies. Reading and writing in context. London: Routledge.

Canagarajah, S. (2002a). Multilingual writers and the academic community: Towards a critical relationship. Journal of English for Academic Purposes, 1, 29-44.

Canagarajah, A. S. (2002b). Critical academic writing and multilingual students. Ann Arbor, MI: University of Michigan Press.

Casanave, C. P. (1995). Locating interactions: Constructing contexts for composing in a graduate sociology program. In D. Belcher, \& G. Brain (Eds.), Academic writing in a second language. Essays on research \& pedagogy (pp. 83-110). Norwood, NJ: Ablex.

Casanave, C. P. (2002). Writing games: Multicultural case studies of academic literacypractices in higher education. Mahwah, NJ: Lawrence Erlbaum.

Hirvela, A., \& Belcher, D. (2001). Coming back to voice. The multiple voices and identities of mature multilingual writers. Journal of Second Language Writing, 10, 83-106.

Hull, G., \& Schultz, K. (2001). Literacy and learning out of school: A review of theory and research. Review of Educational Research, 71(4), 575-611. 
Ivanic, R., \& Camps, D. (2001). I am how I sound: Voice as self-representation in L2 writing. Journal of Second Language Writing, 10(1-2), 3-33.

Klineberg, O., \& Hull, W. F. (1979). At a foreign university: An international study of adaptation and coping. New York: Praeger.

Kobayashi, M. (2003). The role of peer support in students' accomplishment of oral academic tasks. Canadian Modern Language Review, 59, 337-368.

Norton, P. B. (1995). Social identity, investment, and language learning. TESOL Quarterly, 29, 9-31.

Norton, B. (1997). Language, identity, and the ownership of English. TESOL Quarterly, 31, 409-429.

Norton, B. (2000). Identity and language learning: Gender, ethnicity and educational change. Essex, UK: Pearson Education Limited.

Norton, B., \& Toohey, K. (2001). Changing perspectives on good language learners. TESOL Quarterly, 35(2), 307-321.

Morita, N. (2000). Discourse socialization through oral classroom activities in a TESL graduate program. TESOL Quarterly, 34, 279-310.

Morita, N. (2004). Negotiating participation and identity in second language academic communities. TESOL Quarterly, 38, 573-603.

Prior, P. (1995). Redefining the task: An ethnographic examination of writing and response in graduate seminars. In D. Belcher, \& G. Brain (Eds.), Academic writing in a second language: Essays on research \& pedagogy (pp. 26-43). Norwood, NJ: Ablex.

Street, B. V. (1984). Literacy in theory and practice. Cambridge, UK: Cambridge University Press.

Street, B. (Ed.). (1993). Cross-cultural approaches to literacy. Cambridge: England, Cambridge University Press.

Toohey, K. (1998). Breaking them up, taking them away: ESL students in grade 1. TESOL Quarterly, 32, 61-84.

\section{Copyrights}

Copyright for this article is retained by the author(s), with first publication rights granted to the journal.

This is an open-access article distributed under the terms and conditions of the Creative Commons Attribution license (http://creativecommons.org/licenses/by/3.0/). 